Check for updates

Cite this: RSC Adv., 2018, 8, 30573

\title{
Preparation of Ru(II)@oligonucleotide nanosized polymers as potential tumor-imaging luminescent probes $\uparrow$
}

\author{
Geng-Nan Yu,,$^{\mathrm{a}}$ Jun-Chao Huang, $\dot{t}^{\mathrm{b}} \mathrm{Li}$ Li, ${ }^{\mathrm{a}}$ Ruo-Tong Liu, ${ }^{\mathrm{a}} \mathrm{Jie-Qiong} \mathrm{Cao,}{ }^{\mathrm{c}}$ \\ Qiong Wu, (D) *ac Shuang-Yan Zhang, ${ }^{a}$ Cheng-Xi Wang, *a Wen-Jie Mei (D) *ad \\ and Wen-Jie Zheng ${ }^{\mathrm{C}}$
}

\begin{abstract}
The development of $\mathrm{Ru}(\mathrm{II})$ complexes as luminescent probes has attracted increasing attention in recent decades. In this study, the nanosized polymers of two $\mathrm{Ru}(\|)$ complexes $\left[\mathrm{Ru}(\mathrm{phen})_{2}(\mathrm{dppz})\right]\left(\mathrm{ClO}_{4}\right)_{2}(1$, phen $=$ 1,10-phenanthrolin; dppz = dipyrido[3,2-a:2', 3'-c]phenazine $)$ and $\left[\mathrm{Ru}(\text { phen })_{2}\left(\mathrm{Br}\right.\right.$-dppz)] $\left(\mathrm{ClO}_{4}\right)_{2}(2, \mathrm{Br}$-dppz $=$ 11-bromodipyrido[3,2-a:2', $3^{\prime}$-c]phenazine) with oligonucleotides were prepared and investigated as potential tumor-imaging probes. The formation of the nanosized polymers, which had an average width of 125-438 nm and an average height of 3-6 nm, for 1 and 2aoligonucleotides were observed through atomic force microscopy. The emission spectra indicated that the luminescence of 1 and 2 markedly increased after binding to oligonucleotides and double-strand DNA (calf thymus DNA), respectively. Moreover, further studies indicated that 1@oligonucleotides and 2@oligonucleotides can easily enter into tumor cells and selectively highlight the tumor area in the zebrafish bear xenograft tumor (MDA-MB-231). In summary, this study demonstrated that 1@oligonucleotides and 2@oligonucleotides could be developed as potential tumor-imaging luminescent probes for clinical diagnosis and therapy.
\end{abstract}

Received 26th June 2018
Accepted 15th August 2018

DOI: $10.1039 / \mathrm{c} 8 \mathrm{ra0} 5454 \mathrm{a}$

rsc.li/rsc-advances

In the past two decades, $\mathrm{Ru}(\mathrm{II})$ complexes have been

\section{Introduction}

Fluorescence imaging has become an increasingly significant approach among modern medical treatments for tumor diagnosis and surgery. ${ }^{\mathbf{1}, 2}$ The development of confocal fluorescence microscopy has enabled the early detection of tumor tissues by medical professionals through fluorescence imaging, ${ }^{3}$ and fluorescence-guided surgery can aid surgeons in identifying and removing malignant lesions. ${ }^{4}$ Although current clinical imaging agents are excellent for cellular uptake and have low toxicity, ${ }^{5}$ they suffer from short stokes shifts, short luminescence lifetimes, and photobleaching. ${ }^{6}$ An ideal luminophore for cellular imaging should be photostable, have a high quantum yield, possess good cell permeability, and exhibit low cytotoxicity. ${ }^{7}$ Novel luminescence probes should satisfy these requirements in the future.

${ }^{a}$ School of Pharmacy, Guangdong Pharmaceutical University, Guangzhou, 510006, China.E-mail: wenjiemei@126.com; wuqiongniu.1113@163.com; hiwcx@hotmail. com

${ }^{b}$ Traditional Chinese Medicine College, Guangdong Pharmaceutical University, Guangzhou, 510006, China

${ }^{c}$ School of Chemistry, Jinan University, Guangzhou, 510632, China

${ }^{d}$ Guangdong Province Engineering Technology Centre for Molecular Probe and Biomedicine Imaging, Guangzhou, 510006, China

$\dagger$ Electronic supplementary information (ESI) available. See DOI: 10.1039/c8ra05454a

\$ Equally contribution. requently investigated as luminescence probes because of their excellent photostability, large stokes shifts, excellent photophysical properties, and long lifetimes. ${ }^{8} \mathrm{Ru}(\mathrm{dppz})$ systems reported as DNA probes, ${ }^{\mathbf{9}, 10}$ such as complex $\mathbf{1}$, have attracted considerable interest because of the outstanding photophysical and photochemical properties of $\mathrm{Ru}(\mathrm{II})$ complexes and the light switch-on effect. Although this complex has no luminescence in water solutions, it can exhibit strong luminescence when intercalating with DNA. ${ }^{11}$ Moreover, several studies have reported that $\mathrm{Ru}(\mathrm{II})$ complexes can be utilized in imaging subcellular structures, such as membranes, ${ }^{12}$ endoplasmic reticulum, ${ }^{13}$ lysosomes, ${ }^{14}$ mitochondria, ${ }^{15}$ and nuclei. ${ }^{16}$ In previous works, $\mathrm{Ru}(\mathrm{II})$ complexes have been modified with cellpenetrating peptides, ${ }^{17}$ biotins,${ }^{18}$ estradiols, ${ }^{19}$ and oligonucleotides $^{20}$ to improve their cellular uptake and decrease their cytotoxicity. An increasing number of studies on the use of $\mathrm{Ru}$ (II) complexes as luminescence probes have confirmed the great potential of such complexes in clinical imaging. Nonetheless, the clinical application of $\mathrm{Ru}$ (II) complexes is still hampered by several limitations, particularly the lack of tumor targeting and location.

Drug targeting is an attractive concept because it can enhance the therapeutic effects and reduce the system toxicity. ${ }^{21}$ Drug targeting can be divided into two methods: active targeting and passive targeting. Active targeting can be achieved through several strategies, such as antibodies, ${ }^{22}$ aptamers,${ }^{23}$ and 
peptides, ${ }^{24}$ which are the ligands in angiogenic blood vessels or the cell membrane. Drugs can be modified with these ligands to target tumor cells. However, these active targeting methods are unsuitable for solid tumor tissues, thereby limiting their clinical applications. In recent years, the use of nanoparticles for passive targeting ${ }^{25}$ has attracted considerable attention in cancer therapy and diagnosis. ${ }^{26}$ Nanoparticles are defined as submicron ( $<1 \mathrm{~mm}$ ) colloidal systems, which can be classified as nanospheres or nanocapsules depending on the preparation process. ${ }^{27}$ Nanocapsules are vesicular systems that encapsulate drugs in an aqueous or oily cavity formed from a single polymeric membrane. Nanospheres are matrix systems from which drugs are dispersed throughout the particles. Nanoparticles deliver drugs to tumor tissues in vivo via physiological barriers, and the size of the nanoparticles affects the biodistribution in vivo. ${ }^{28}$ Owing to solid tumors with abundant abnormal blood vessel and great membrane permeability, the nano-sized macromolecular anticancer drugs can easily penetrated into tumor cells and largely enriched in tumor tissues through EPRbased selective anticancer nanotherapy. Then, the selective high local concentration of nano-sized anticancer drugs have been consider as a potential tumor targeting inhibitor with minimal side effects in both preclinical and clinical settings. ${ }^{29}$ Recent reports have demonstrated that drugs incorporated into polymeric particles display high selectivity and local concentration. ${ }^{30}$ For example, the anticancer drug DOX, when carried by nanoparticles, shows distribution in whole body for heart, liver, spleen, lung, kidney, and so on, but also enhanced accumulation $^{31}$ and selective delivery in solid tumors. As such, DOXcontaining nanoparticles have been in clinical trials.

Therefore, to reduce the side effects of $\mathrm{Ru}(\mathrm{II})$ complexes as luminescent imaging agents and increase their concentration in tumor tissues, two Ru(II) complexes (Scheme 1) $\left[\mathrm{Ru}(\mathrm{phen})_{2}(-\right.$ $\mathrm{dppz})]\left(\mathrm{ClO}_{4}\right)_{2}(\mathbf{1}$, phen $=1,10$-phenanthrolin; dppz $=$ dipyrido $\left[3,2-a: 2^{\prime}, 3^{\prime}-c\right]$ phenazine $)$ and $\left[\mathrm{Ru}(\text { phen })_{2}(\mathrm{Br}-\mathrm{dppz})\right]\left(\mathrm{ClO}_{4}\right)_{2}(2, \mathrm{Br}-$

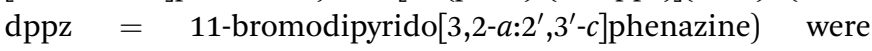
designed as Ru(II)@oligonucleotide nanosized polymers and constructed. The atomic force microscopy (AFM) results of the $\mathrm{Ru}(\mathrm{II}) @$ oligonucleotide indicated that $\mathrm{Ru}(\mathrm{II})$ complexes can selectively induce oligonucleotides to transform into nanosized polymers. The luminescence of the $\mathrm{Ru}(\mathrm{II})$ complexes was enhanced after the addition of oligonucleotides. The stability of the Ru(II)@oligonucleotide nanosized polymers was assessed through electronic spectroscopy and circular dichroism (CD) spectroscopy. The results revealed that both $\mathbf{1}$ and $\mathbf{2}$ could selectively stabilize and bind to oligonucleotides, and that the

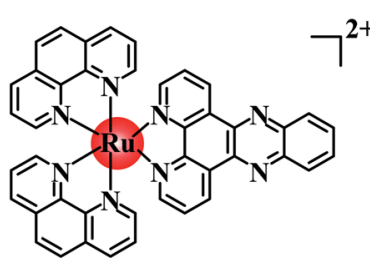

1

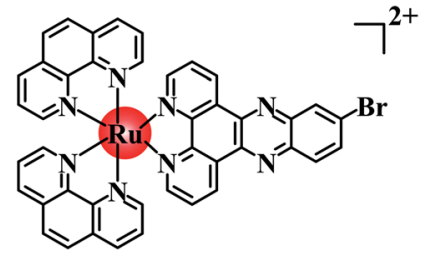

2
Scheme 1 Molecular structures of 1 and 2
Ru(II)@oligonucleotide nanosized polymers should be stable. Further study shown that Ru(II)@oligonucleotide nanosized polymers was selectively localized in tumor cells with strong phosphorescence in cellular and zebrafish xenografts model. These findings may suggest that 1 and 2@oligonucleotide nanosized polymers can be utilized as potential luminescence probes in tumor diagnosis and therapy.

\section{Results and discussion}

\section{Synthesis and characterization}

The target compounds 1 and 2 have been prepared by heating at reflux for $6 \mathrm{~h}$ under $\mathrm{N}_{2}$ atmosphere. The yield for $\mathbf{1}$ and 2 is about 67 and $61 \%$, respectively. The mass spectra in acetonitrile exhibited a peak at $\mathrm{m} / \mathrm{z} 372.5(100 \%)$ for 1 and at 412.3 for 2 $(100 \%)$ which was ascribed to $\left[\mathrm{M}-2 \mathrm{ClO}_{4}{ }^{-}\right]^{2+}$ and agreed with the theoretical value. The chemical shift $(\delta)$ of 1 in ${ }^{1} \mathrm{H}$ NMR at 9.61 $(\mathrm{d}, J=1.2 \mathrm{~Hz}, 1 \mathrm{H}), 9.59-9.59(\mathrm{~m}, 1 \mathrm{H}), 8.81$ (d, $J=1.2 \mathrm{~Hz}, 1 \mathrm{H})$, $8.80(\mathrm{t}, J=1.3 \mathrm{~Hz}, 2 \mathrm{H}), 8.78(\mathrm{~d}, J=1.3 \mathrm{~Hz}, 1 \mathrm{H}), 8.41(\mathrm{~s}, 4 \mathrm{H}), 8.28$ $(\mathrm{dt}, J=4.5,2.3 \mathrm{~Hz}, 2 \mathrm{H})$ and $8.21-8.18(\mathrm{~m}, 4 \mathrm{H}) \mathrm{ppm}$ can be attributed to eight $\mathrm{H}$ atoms in phen ligands, respectively. The chemical shift attributed to the phenanthroline ring appeared at (7.78-8.52) of $7.78(\mathrm{dd}, J=8.3,5.3 \mathrm{~Hz}, 2 \mathrm{H}), 7.90(\mathrm{dd}, J=6.8$, $4.0 \mathrm{~Hz}, 2 \mathrm{H})$ and $8.52(\mathrm{dt}, J=6.4,3.2 \mathrm{~Hz}, 2 \mathrm{H}) \mathrm{ppm}$. The chemical shift at $8.07(\mathrm{dd}, J=5.2,1.2 \mathrm{~Hz}, 2 \mathrm{H})$ and $7.82(\mathrm{dd}, J=8.3,5.3 \mathrm{~Hz}$, $2 \mathrm{H})$ ppm can be attributes to $\mathrm{H} 5$ and $\mathrm{H} 6$ in co-ligand phenanthroline. For complex 2, the chemical shift $(\delta)$ at $9.52(\mathrm{~d}, J=$ $1.2 \mathrm{~Hz}, 1 \mathrm{H}), 9.50(\mathrm{dd}, J=2.4,1.3 \mathrm{~Hz}, 1 \mathrm{H}), 9.48(\mathrm{~d}, J=1.3 \mathrm{~Hz}$, $1 \mathrm{H}), 8.83-8.80(\mathrm{~m}, 2 \mathrm{H}), 8.80(\mathrm{~d}, J=1.0 \mathrm{~Hz}, 1 \mathrm{H}), 8.41$ (d, $J=$ $1.2 \mathrm{~Hz}, 3 \mathrm{H}), 8.28(\mathrm{dd}, J=5.3,1.2 \mathrm{~Hz}, 1 \mathrm{H}), 8.25(\mathrm{t}, J=3.0 \mathrm{~Hz}, 1 \mathrm{H})$, $8.23(\mathrm{dd}, J=5.4,1.7 \mathrm{~Hz}, 1 \mathrm{H}), 8.21$ (dd, $J=4.5,2.5 \mathrm{~Hz}, 1 \mathrm{H}), 8.20$ (d, $J=1.3 \mathrm{~Hz}, 1 \mathrm{H})$, and 8.08 (ddd, $J=5.2,2.5,1.2 \mathrm{~Hz}, 2 \mathrm{H}) \mathrm{ppm}$ can be attributed to eight $\mathrm{H}$ atoms in phen ligands, respectively. The chemical shift attributed to the phenanthroline ring appeared at (7.90-8.52) of $7.78(\mathrm{dd}, J=8.3,5.3 \mathrm{~Hz}, 2 \mathrm{H}), 7.92-$ $7.87(\mathrm{~m}, 2 \mathrm{H})$ and $8.32(\mathrm{dt}, J=5.4,2.7 \mathrm{~Hz}, 1 \mathrm{H}) \mathrm{ppm}$. The chemical shift at $8.78(\mathrm{~s}, 1 \mathrm{H}), 7.83(\mathrm{td}, J=8.1,5.3 \mathrm{~Hz}, 2 \mathrm{H})$ and $8.63(\mathrm{~d}, J=2.2 \mathrm{~Hz}, 1 \mathrm{H}) \mathrm{ppm}$ can be attributed to $\mathrm{H} 4, \mathrm{H} 5$ and $\mathrm{H} 6$ in co-ligand phenanthroline (Fig. S2 $\dagger$ ).

\section{Preparation and characterization of the nanosized polymers}

$\mathrm{Ru}$ (II) complexes were dissolved by dimethyl sulfoxide and then diluted to $100 \mu \mathrm{M}$ solution by Tris- $\mathrm{HCl} \mathrm{KCl}$ or NaCl buffer ( $\mathrm{pH}$ $=7.2)([\mathrm{KCl}]=0.1 \mathrm{M},[\mathrm{NaCl}]=0.1 \mathrm{M})$. The oligonucleotides or CT-DNA were dissolved and diluted to $100 \mu \mathrm{M}$ solution by Tris$\mathrm{HCl} \mathrm{KCl}$ or $\mathrm{NaCl}$ buffer $(\mathrm{pH}=7.2)([\mathrm{KCl}]=0.1 \mathrm{M},[\mathrm{NaCl}]=0.1$ $\mathrm{M})$. The oligonucleotides or CT-DNA solution $(100 \mu \mathrm{M})$ and $\mathrm{Ru}(\mathrm{II})$ complexes $(100 \mu \mathrm{M})$ were well mixed in an Eppendorf tube.

AFM was conducted to investigate the nanosized polymers formed from 1 and $\mathbf{2}$ with oligonucleotides. The sequence of the oligonucleotides was $5^{\prime}$-TGGGGAGGGTGGGGAGGGTGGGGAAGG-3'. The morphologies and sizes of the oligonucleotide nanosized polymers that were treated by the complexes are shown in Fig. 1A and B. Abundant lacunose DNA particles and $\mathrm{Ru}(\mathrm{II})$ molecules associated with each other into a higher 
ordered conglomerate and self-assembled into nanosized polymers. ${ }^{32}$ Both 1 and 2@oligonucleotides displayed an irregular rotundity shaped. The 1@oligonucleotide nanosized polymers had an average width of $116-170 \mathrm{~nm}$ and an average height of 3-5 $\mathrm{nm}$. The 2@oligonucleotide nanosized polymers had an average width of 375-422 $\mathrm{nm}$ and an average height of 5$6 \mathrm{~nm}$ (Fig. S4 $\dagger$ ). As 1 and 2 were added, the CT-DNA condensed into vast amorphous and irregular particles. These particles, which were loose and net-like, had an average width of 50$400 \mathrm{~nm}$ and an average height of 1-3 nm (Fig. S5†). ${ }^{33-35}$ The sphere-like morphology of the Ru(II)@oligonucleotides considerably differed from the net-like morphology of the Ru(II)@CTDNA particles, suggesting that the conformation of oligonucleotides or CT-DNA was changed after being treated by $\mathbf{1}$ and 2 . Furthermore, the size of the oligonucleotide nanosized polymers treated by complexes was larger than that of the CT-DNA presumably because of the higher affinity of 1 and 2 binding to oligonucleotides. ${ }^{36}$ Moreover, the size of the 2@oligonucleotides was larger than that of the 1@oligonucleotides possibly because of the effects of the substituents on the ligand. These results unambiguously differentiated the morphological characteristics of oligonucleotides and CT-DNA in the presence of $\mathbf{1}$ and 2, respectively, confirming that the complexes can selectively induce oligonucleotides to form nanosized polymers.

To investigate the surface properties and stability of the polymers, the TEM (Fig. S7 $\dagger$ ) and particles size (Fig. S8 $\dagger$ ) of $\mathrm{Ru}$ (II)@oligonucleotides and Ru(II)@CT-DNA were tested. It can

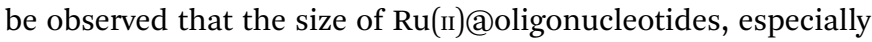
the 2@oligonucleotides, was larger than that of Ru(II)@CT-DNA. For oligonucleotides, upon the addition of 1 and 2, DNA condensates exerted more tight nanosized polymers, especially for1@ooligonucleotides with excellent dispersivity which complex 1 exhibited greater binding affinity to oligonucleotides than 2. However for CT-DNA, Ru@CT-DNA presented smaller size and loose polymers with the addition of $\mathbf{1}$ and 2. It is suggested that 1 and 2 showed weak binding affinity to CT-DNA. Besides, it is found that the size of 1@CT-DNA and 2@CTDNA exerted big fluctuation in 7 days, but the size of 1@oligonucleotides and 2@oligonucleotides exhibited some certain degree changes and kept a excellent stability in 7 days. These results were agreement with above result, and it is indicated that $\mathbf{1}$ and $\mathbf{2}$ may display great affinity to oligonucleotide.

\section{DNA-binding behaviour of Ru(II) complexes with oligonucleotides}

Fluorescence spectra titration. The enhancement of the steady-state luminescence of $\mathbf{1}$ and $\mathbf{2}$ in the presence of oligonucleotides and CT-DNA was evaluated, as shown in Fig. 2. When excited at $450 \mathrm{~nm}$ in Tris- $\mathrm{HCl} \mathrm{KCl}$ or $\mathrm{NaCl}$ (pH 7.2) buffer at room temperature, both 1 and 2 emitted strong luminescence in the range 550-650 $\mathrm{nm}$ with the maximum at 577 and $595 \mathrm{~nm}$, respectively. The Stokes shifts were 127 and $145 \mathrm{~nm}$, respectively. Upon the addition of oligonucleotides and CT-DNA, the intensities of 1 and 2 were enhanced by degrees (Fig. 3A). In the presence of oligonucleotides, the relative intensities $\left(I / I_{0}\right)$ of 1 and 2 were 2.89 and 2.59, respectively, suggesting that 1 and 2 may bind to oligonucleotides in a groove binding mode. ${ }^{37}$ In the presence of CT-DNA, the relative intensities $\left(I / I_{0}\right)$ of $\mathbf{1}$ and 2 were 2.74 and 2.04, respectively, possibly because the formation of $\mathrm{Z}$ DNA enhanced the luminescence intensity of these $\mathrm{Ru}$ (II) complexes. $^{38}$ As the nucleotide concentration was increased, Ru(II)@oligonucleotides exhibited a more significantly enhanced luminescence than Ru(II)@CT-DNA. These results

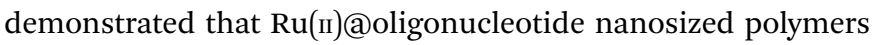
had stronger luminescence intensity than free complexes and $\mathrm{Ru}(\mathrm{II}) @$ CT-DNA particles, indicating that $\mathrm{Ru}(\mathrm{II})$
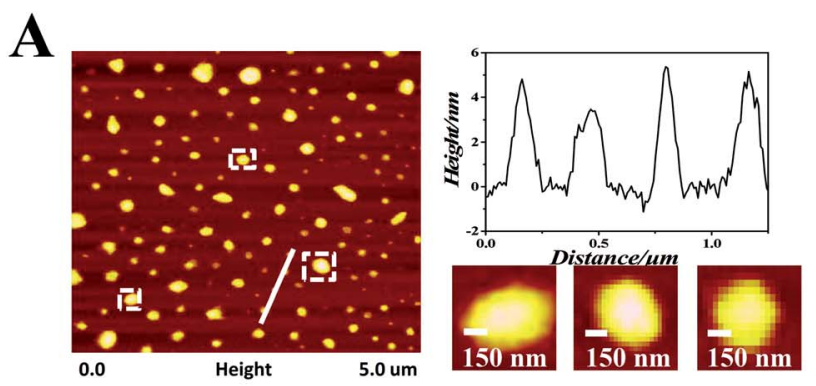

\section{B}
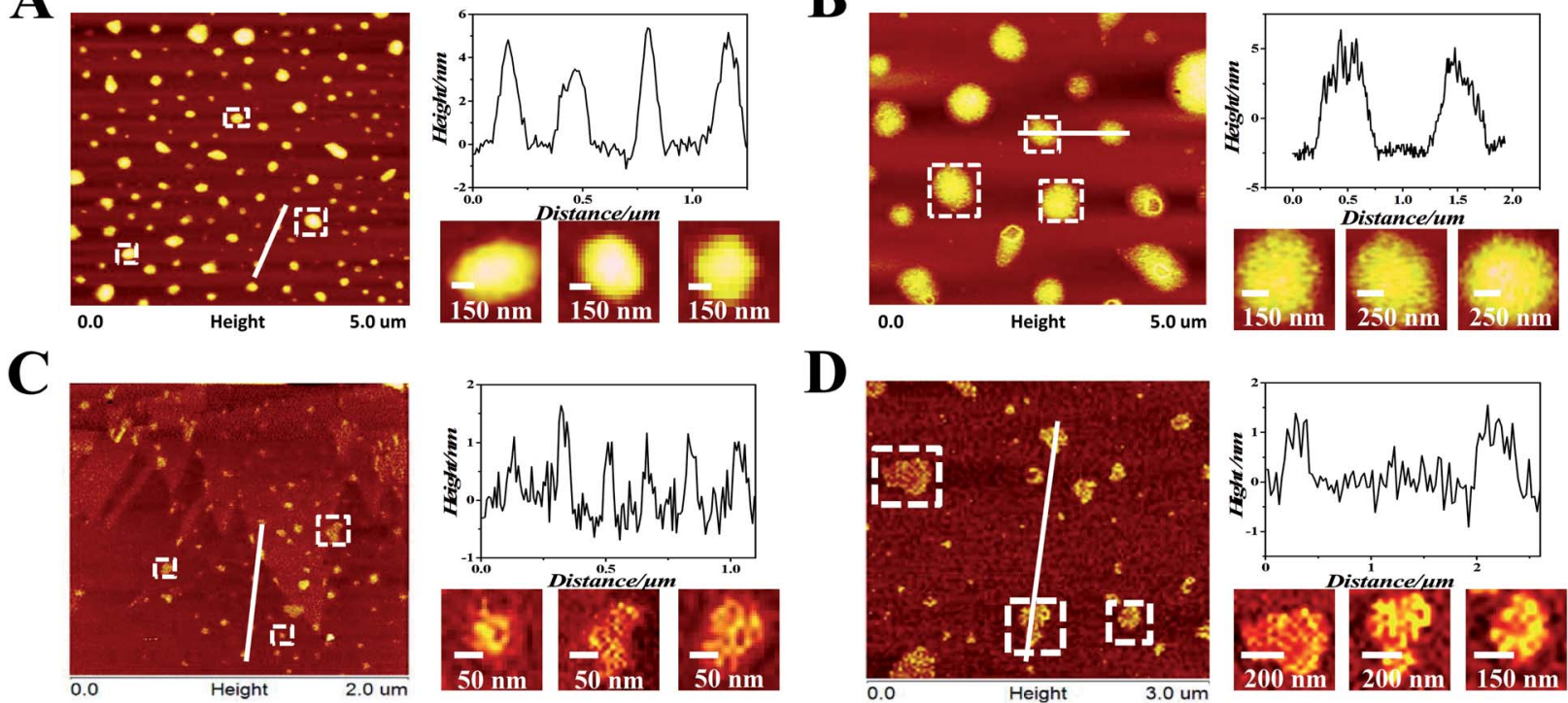

D
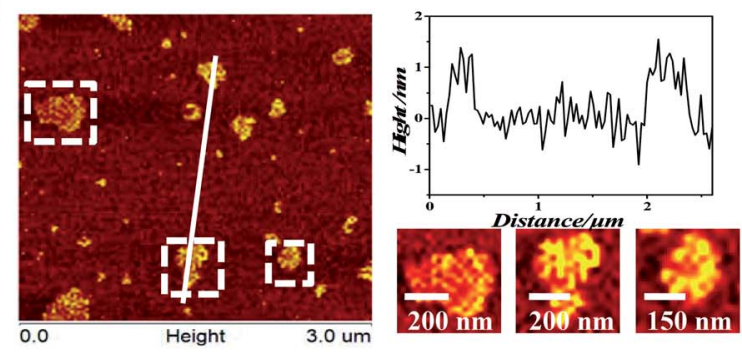

Fig. 1 (A) AFM images of oligonucleotides after being treated by 1 (in $\mathrm{pH} 7.2$ Tris- $\mathrm{HCl} \mathrm{KCl} \mathrm{buffers).} \mathrm{(B)} \mathrm{AFM} \mathrm{images} \mathrm{of} \mathrm{oligonucleotides} \mathrm{after} \mathrm{being}$ treated by 2 (in pH 7.2 Tris- $\mathrm{HCl} \mathrm{KCl} \mathrm{buffers).} \mathrm{(C)} \mathrm{AFM} \mathrm{images} \mathrm{of} \mathrm{CT-DNA} \mathrm{after} \mathrm{being} \mathrm{treated} \mathrm{by} 1$ (in pH 7.2 Tris- HCl NaCl buffers). (D) AFM images of CT-DNA after being treated by 2 (in pH 7.2 Tris- $\mathrm{HCl} \mathrm{NaCl}$ buffers). [Ru] $=100 \mu \mathrm{M}$, [oligonucleotides] $=100 \mu \mathrm{M}$, [CT-DNA] $=100 \mu \mathrm{M}$. 
A

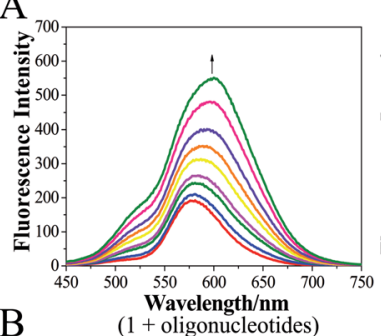

B
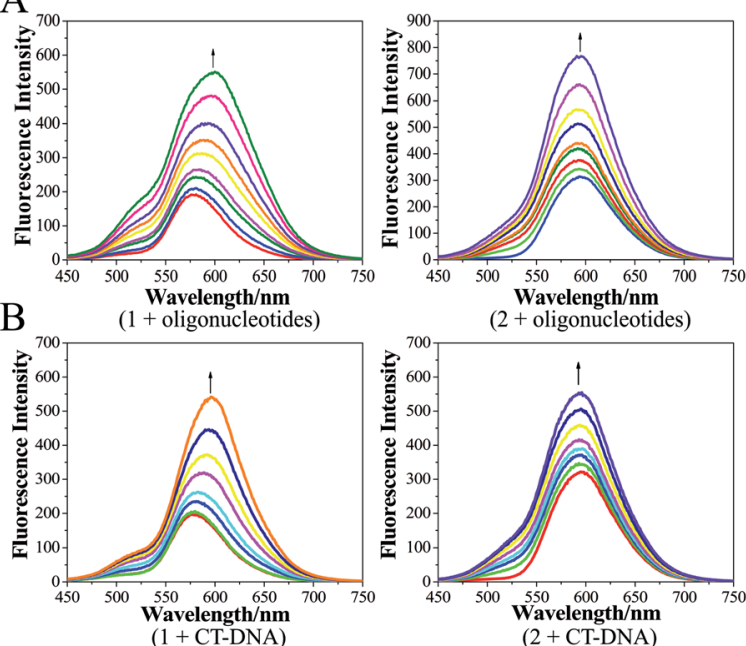
$(2+$ oligonucleotides $)$

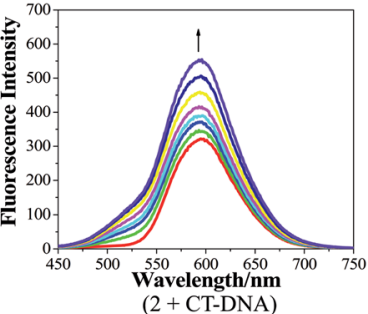

Fig. 2 (A) Changes in the luminescence intensities of 1 and 2 in the absence and presence of oligonucleotides. $[\mathrm{Ru}]=100 \mu \mathrm{M}$, [oligonucleotides] $=0.067 n \mu \mathrm{M}, n=0,1,2 \ldots$ (in $\mathrm{pH} 7.2$ Tris- $\mathrm{HCl} \mathrm{KCl} \mathrm{buffers)}$. (B) Changes in the luminescence intensities of 1 and 2 in the absence and presence of CT-DNA. $[\mathrm{Ru}]=100 \mu \mathrm{M},[\mathrm{CT}-\mathrm{DNA}]=0.067 n \mu \mathrm{M}, n=$ $0,1,2 \ldots$ (in $\mathrm{pH} 7.2$ Tris- $\mathrm{HCl} \mathrm{NaCl}$ buffers).

(a)oligonucleotide nanosized polymers can be utilized as luminescence imaging agents.

Electronic spectra titration. The binding affinity of both complexes with oligonucleotides and CT-DNA was investigated by electronic spectra titration experiments. Electronic spectroscopy is one of the most common methods for analyzing the interactions of transition metal complexes with biological molecules. In general, $\mathrm{Ru}(\mathrm{II})$ complexes that exhibit absorption during electronic spectroscopy may undergo hypochromism and redshift in the presence of DNA, and the degree of variation depends on the binding affinity. ${ }^{39}$ As shown in Fig. 4, the electronic spectra of 1 in Tris- $\mathrm{HCl}$ buffer $(\mathrm{pH}=7.2)$ solution showed characteristic IL (intraligand charge transfer) absorption in the range of $250-300 \mathrm{~nm}$ with the maximum at $264 \mathrm{~nm}$. A weak absorption band was observed at $439 \mathrm{~nm}$, which could be attributed to metal-ligand charge transfer (MLCT) absorption.
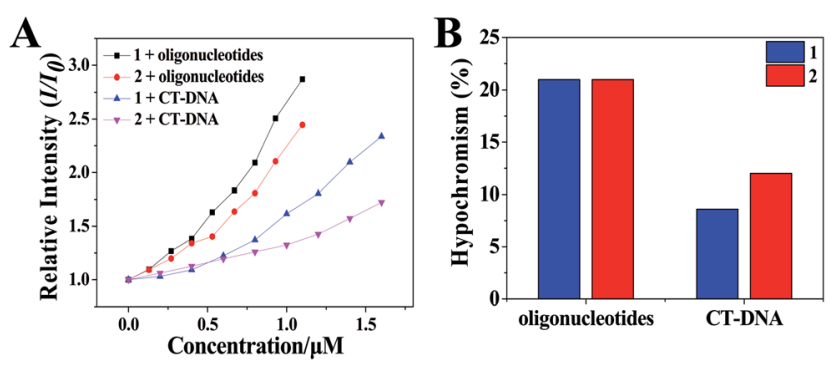

Fig. 3 (A) The relative intensity $\left(/ / I_{0}\right)$ of 1 and 2 with increasing concentration of oligonucleotides or CT-DNA. [Ru] $=20 \mu \mathrm{M}$, [oligonucleotides] $=0.067 n \mu \mathrm{M}, n=0,1,2 \ldots,[$ [CT-DNA] $=0.067 n \mu \mathrm{M}, n=0$, $1,2 \ldots$, (in $\mathrm{pH} 7.2 \mathrm{Tris}-\mathrm{HCl} \mathrm{KCl}$ or $\mathrm{NaCl}$ buffers). (B) Hypochromic effect of the changes of 1 and 2 between oligonucleotides and CT-DNA, [Ru] $=20 \mu \mathrm{M}$, [oligonucleotides] $=100 \mu \mathrm{M}$, [CT-DNA] $=100 \mu \mathrm{M}$, (in pH 7.2 Tris- $\mathrm{HCl} \mathrm{KCl}$ or $\mathrm{NaCl}$ buffers).
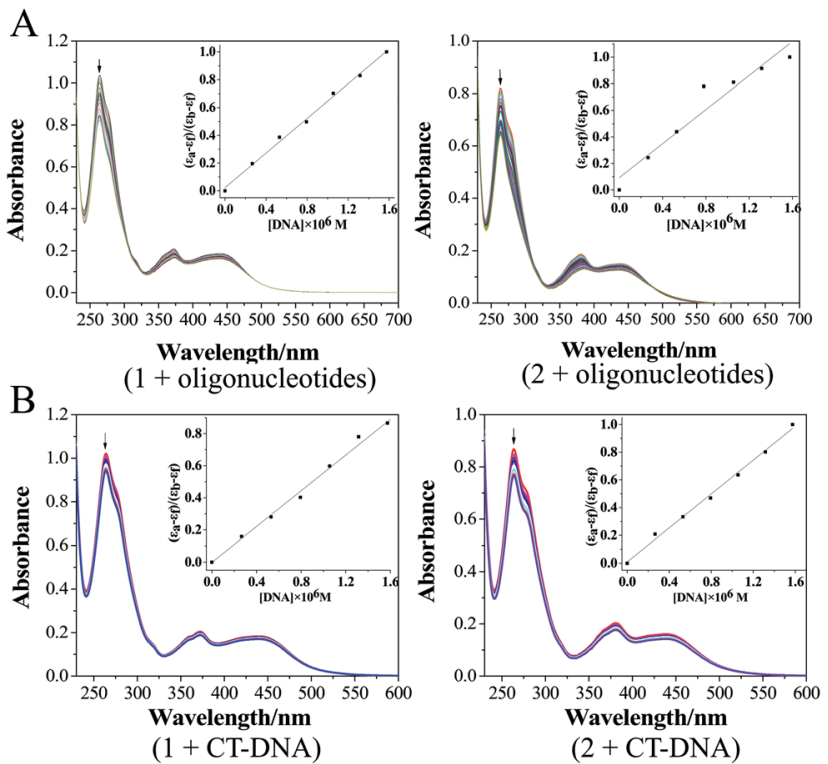

Fig. 4 (A) Electronic spectra of 1 and 2 in the absence and presence of oligonucleotides in the Tris- $\mathrm{HCl} \mathrm{KCl}$ buffer $(\mathrm{pH}$ 7.2). ([Ru] $=20 \mu \mathrm{M}$, [oligonucleotides] $=0.067 n \mu \mathrm{M}, n=0,1,2 \ldots$ ); (B) electronic spectra of 1 and 2 in the absence and presence of CT-DNA in the Tris- $\mathrm{HCl} \mathrm{NaCl}$ buffer (pH 7.2). ([Ru] $=20 \mu \mathrm{M},[\mathrm{CT}-\mathrm{DNA}]=0.067 n \mu \mathrm{M}, n=0,1,2 \ldots)$.

For 2, the characteristic IL and MLCT absorptions appeared at 263.5 and $438 \mathrm{~nm}$, respectively. Upon the addition of oligonucleotides, the hypochromism value was $21 \%$ for both 1 and 2 at the IL absorption band, and binding constants for $\mathbf{1}$ and $\mathbf{2}$ with oligonucleotides were 4.8 and $6.5 \times 10^{7} \mathrm{M}^{-1}$, respectively. When CT-DNA was added, the hypochromism values of 1 and 2 at the IL absorption band were $8.6 \%$ and $12 \%$, and the binding constants
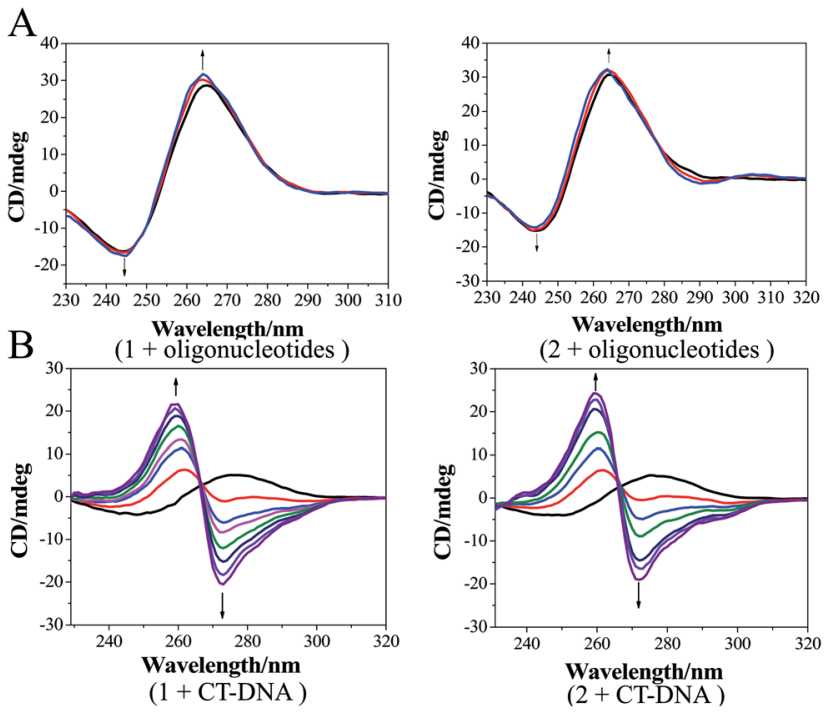

Fig. 5 (A) CD titration spectra of oligonucleotides with increasing amounts of 1 and 2 in the incubation buffer, $[R u]=0,2.660,5.305$, 7.937, 10.554, 13.158, 15.748, $18.325 \mu \mathrm{M}$, [oligonucleotides] $=100 \mu \mathrm{M}$. (B) CD titration spectra of CT-DNA with increasing amounts of 1 and 2 in the incubation buffer, $[\mathrm{Ru}]=0,2.660,5.305,7.937,10.554,13.158$, $15.748,18.325 \mu \mathrm{M},[\mathrm{CT}-\mathrm{DNA}]=100 \mu \mathrm{M}$. 
for 1 and 2 with CT-DNA were 2.7 and $0.7 \times 10^{7} \mathrm{M}^{-1}$, respectively. Compared with $\left[\mathrm{Ru}(\mathrm{bpy})_{2}(\mathrm{bppp})\right]^{2+}$, these data indicated that both 1 and 2 could bind to oligonucleotides with high affinity ${ }^{\mathbf{4 0}}$ and that the nanosized polymers of Ru(II)@oligonucleotide may possess a greater robust system stability.

Circular dichroism spectra. Furthermore, the conformation of oligonucleotides and CT-DNA was confirmed by CD spectroscopy in the presence of $\mathbf{1}$ and 2. CD spectroscopy is one of the most common and convenient methods for detecting DNA conformational changes. ${ }^{41}$ The CD spectra of oligonucleotides showed a positive signal in the range of $254-290 \mathrm{~nm}$ with the maximum at $265 \mathrm{~nm}$ and a negative signal in the range of 220$253 \mathrm{~nm}$ with the maximum at $245 \mathrm{~nm}$. As 1 and 2 increased, the conformation of the oligonucleotides remained unchanged, and the signal was enhanced (Fig. 5A) finding that 1 and 2 can stabilize the structures of oligonucleotides. The CD spectra of CT-DNA es exhibited a strong positive signal in the range of 265-300 $\mathrm{nm}$ with the maximum at $275 \mathrm{~nm}$ and a major negative signal in the range of $230-265 \mathrm{~nm}$ with the maximum at
$248 \mathrm{~nm}$, which are characteristic CD signals of B-form doublestranded DNA. ${ }^{42}$ Upon the addition of Ru(II) complexes, the CD spectra markedly changed (Fig. 5B). For 1, as the original negative peak at $248 \mathrm{~nm}$ and the positive peak at $275 \mathrm{~nm}$ were suppressed, a strong positive peak at about $260 \mathrm{~nm}$ and a negative peak at about $273 \mathrm{~nm}$ appeared, which were the CD signals of Z-DNA. ${ }^{\mathbf{4 1 4 3 - 4 7}}$ The same result was observed for 2 . These finding showed $\mathbf{1}$ and $\mathbf{2}$ can induce the conformation of B-form DNA transformed to Z-form DNA. This phenomenon may give the reminder that the AFM images of $\mathrm{Ru}$ (II) were loose net-like particles, may attribute to the inherently loose structure of Z-DNA, of which the ribose phosphate backbone follows a zigzag course. ${ }^{48}$ Thus, complexes 1 and 2 can bind with oligonucleotides to form stabilizing matrix systems and be selfassembled into nanospheres, and they also can induce the conformation of B-DNA transformed to Z DNA.

In general, intercalation of a compound into DNA is known to cause an observable increase in the viscosity of a DNA solution due to an increase in the distance of base pairs at the intercalation site.
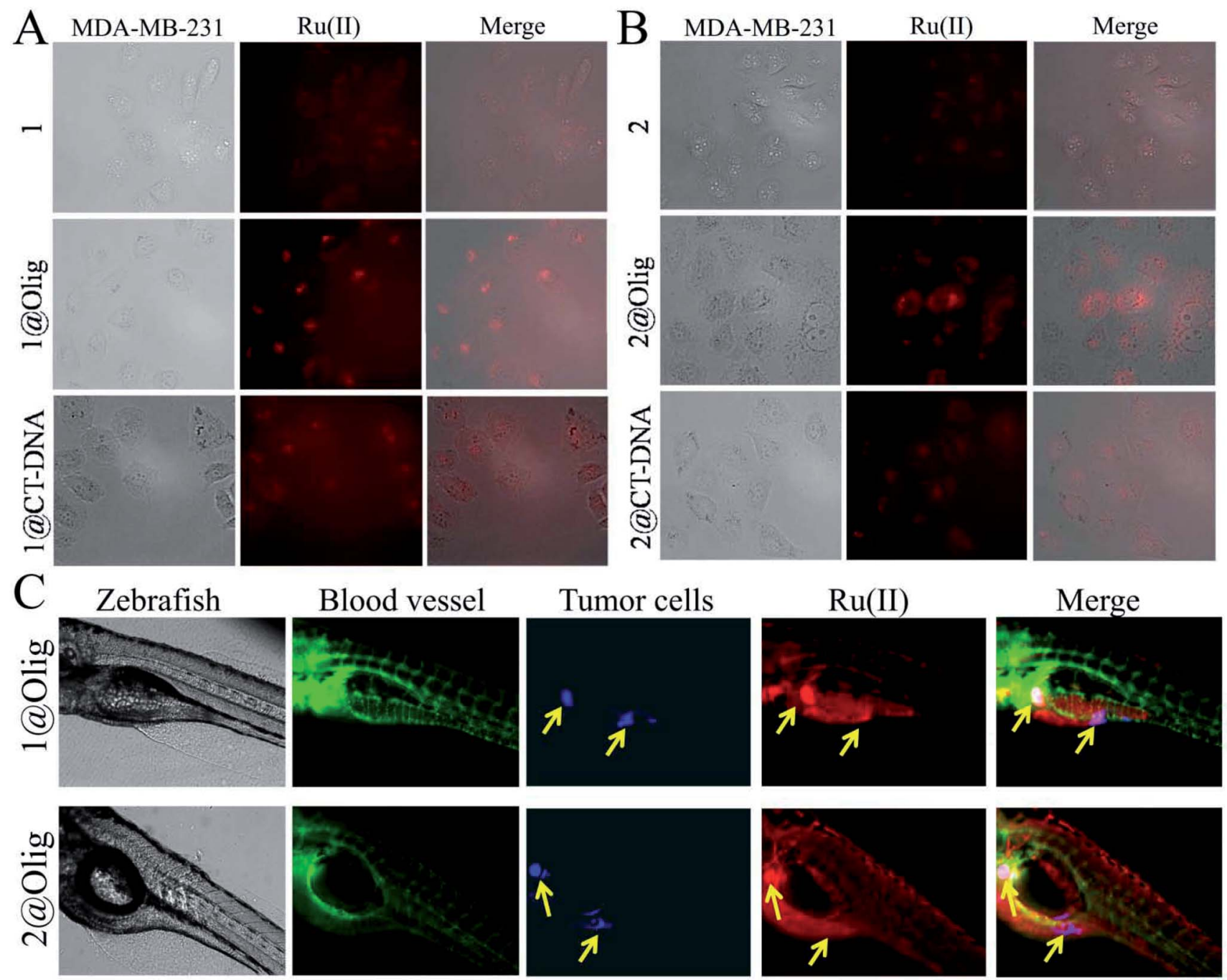

Fig. 6 Selectively imaging tumor cells by Ru(I)@oligonucleotide in vitro and in vivo. (A) MDA-MB-231 cells imaging of 1, 1@oligonucleotide and 1@CT-DNA at $37^{\circ} \mathrm{C}$ for $24 \mathrm{~h}$. (B) MDA-MB-231 cells imaging of 2, 2(aoligonucleotide and 2@CT-DNA at $37^{\circ} \mathrm{C}$ for $24 \mathrm{~h}$. (C) Tumor area highlighted by 1@oligonucleotide and 2@oligonucleotide in zebrafish xenografts model. ([Ru] $=2.5 \mu \mathrm{M}$, [oligonucleotides] $=2.5 \mu \mathrm{M})$. 
Viscosity changes were measured using CT-DNA with increasing concentrations of the complex 1 and 2, as shown in Fig. S9. $\dagger$ The effects of complex 1 and 2 versus $\left[\mathrm{Ru}(\mathrm{bpy})_{3}\right]^{2+}$ on the relative viscosity of rod-like DNA are shown in Fig. S9. $\dagger$ It is well known that $\left[\mathrm{Ru}(\mathrm{bpy})_{3}\right]^{2+}$ interacts with DNA in a classical electronic effect. On increasing the concentration of complex $\mathbf{1}$, the relative viscosity of the DNA increased steadily compared to $\left[\mathrm{Ru}(\mathrm{bpy})_{3}\right]^{2+}$. Moreover, a number of studies have reported that this kind of $\mathrm{Ru}(\mathrm{II})$ complex interact with oligonucleotides through groove binding mode by using molecular docking calculation. ${ }^{8}$ This suggests that complex $\mathbf{1}$ and 2 insert into the base-pairs of CT-DNA via an intercalative mode and interact with oligonucleotides through groove binding mode, which is in agreement with the spectroscopic studies.

Tumor imaging in vitro and in vivo. To evaluate the potential application of $\mathbf{1}$ and 2@oligonucleotides act as the luminescence probe to track tumor cells, the cellular localization observation by fluorescence microscopy was performed. As shown in Fig. 6A and B, after treatment with free complex 1 and 2, weak red phosphorescence was monitor in the cell, which suggested free $\mathrm{Ru}$ (II) complex difficultly penetrated tumor cell membrane. However, when dealt with 1@oligonucleotides and 2@oligonucleotides, it is found that strong red phosphorescence in cell cytoplasm. But, when treated with 1@CT-DNA and 2@CT-DNA (macromolecular nucleic acid modified $\mathrm{Ru}(\mathrm{II})$ complexes), there are little red phosphorescence was observed in cells. ${ }^{36,49}$ These results indicated that 1@oligonucleotides and 2@oligonucleotides could easily enter into cytoplasm and highlight tumor cells, which may attribute to the faster metabolism and higher membrane permeability of tumor cells than that of normal cells. ${ }^{26}$

The zebrafish is an excellent model to study the bioimaging properties of fluorescent probe. Here, building on work with a transgenic zebrafish (fil1:EGFP), MDA-MB-231 breast cancer bearing model, which the blood vessels were labeled green fluorescence, blue fluorescently labelled MDA-MB-231 cells were serially transplanted in limiting dilutions to identify the tumor cells near sub intestinal vessel (SIV) of zebrafish. ${ }^{50}$ Then, the ability of 1@oligonucleotide and 2@oligonucleotide to monitor the tumor bioimaging in zebrafish xenografts model was investigated. The 72 hour post fertilization (hpf) zebrafish larvae were incubated with 1@oligonucleotide and 2@oligonucleotide (2.5 $\mu \mathrm{M})$ for $96 \mathrm{~h}$ at $28.5^{\circ} \mathrm{C}$. As shown in Fig. 6C, when treatment with 1@oligonucleotides and 2@oligonucleotides for $96 \mathrm{~h}$, it is discovered that 1@oligonucleotides and 2@oligonucleotides primarily distributed in intestine, but more distinctly highlight tumor area. That means the nanosized 1@oligonucleotides and 2@oligonucleotides could effectively enriched in tumor cells in vivo. These findings inspired us to develop oligonucleotides modified $\mathrm{Ru}$ (II) complex as an efficient phosphorescent probe to track living tumor cells for future clinical applications.

\section{Conclusions}

In conclusion, the present study established a novel method to construct a Ru(II)@oligonucleotide nanosized polymers to highlight tumor cells through EPR effect in vitro and in vivo. Then, a nanosized functionalized $\mathrm{Ru}(\mathrm{II})$ complexes with great phosphorescence imaging ability can be obtained by oligonucleotide modification. Moreover, it is found that the binding behavior of two $\mathrm{Ru}(\mathrm{II})$ complexes plays a key role in the condensation of DNA to form nanosized polymers. Further studies shown that $\mathrm{Ru}$ (II) (a)oligonucleotide nanosized polymers can distinctly highlight tumor cells in vitro and obviously enrich in tumor area in zebrafish xenografts model. In a word, the present nanosized polymers developed as a potential tumor selective tracker, which is expected to have potential applications of tumor targeting imaging and tracking in vitro and in vivo.

\section{Experimental}

\section{Reagents and materials}

All reagents were purchased from commercial suppliers and used without further purification. Solvents were dried and purified through conventional methods prior to use. $\mathrm{Ru}(\mathrm{III})$ chloride hydrate, $o$-phenylenediamine, and 4-bromo-1,2phenylenediamine were purchased from Aladdin. 1,10Phenanthroline-5,6-dione was prepared by using a previously reported method. ${ }^{51}$ The ligands $\mathrm{dppz}$ and Br-dppz were prepared as described by Norden et al. ${ }^{52}$ All chemicals, including solvents, were obtained from commercial vendors and used as received. Oligonucleotides (5'TGGGGAGGGTGGGGAGGGTGGGGAAGG-3') and calf thymus DNA were purchased from Sangon Biotech (Shanghai) Co. All aqueous solutions were prepared with doubly distilled water. The Tris-HCl buffer (which was utilized in the CD spectroscopy, emission titration, UV titration, and AFM) consisted of $10 \mathrm{mM}$ Tris and $100 \mathrm{mM} \mathrm{NaCl}$ or $100 \mathrm{mM} \mathrm{KCl}$, and the $\mathrm{pH}$ was adjusted to 7.2 by using $\mathrm{HCl}$ solution.

\section{Instruments}

The ESI-MS spectra were obtained in methanol on Agilent 1100 ESI-MS system operated at room temperature. The ${ }^{1} \mathrm{H}$ NMR and ${ }^{13} \mathrm{C}$ NMR spectra were recorded in a dimethyl- $d^{6}$ sulfoxide $\left(\right.$ DMSO- $d^{6}$ ) solution on a Bruker Avance III 500 spectrometer operated at room temperature. The UV-vis absorption spectra were obtained on a Shimadzu UV-2550 spectrophotometer. The steady-state emission spectra were recorded on a RF-5301 fluorescence spectrophotometer. The CD spectra were obtained on a Jasco J810 CD spectrophotometer. AFM imaging was performed with an atomic force microscope (AFM; Bruker, Dimension FastScanTM). Tumor cell imaging was observed on fluorescence microscopy (Leica, DMI8).

\section{Synthesis and characterization}

Synthesis of $\left[\mathrm{Ru}(\mathrm{phen})_{2} \mathrm{dppz}\right]\left(\mathrm{ClO}_{4}\right)_{2}$ (1). 1 was synthesized according to the literature ${ }^{53}$ but with slight modifications. In brief, a mixture of $\left[\mathrm{Ru}(\text { phen })_{2} \mathrm{Cl}_{2}\right] \cdot 2 \mathrm{H}_{2} \mathrm{O}(103.9 \mathrm{mg}, 0.2 \mathrm{mmol})$ and dppz (56.4 mg, $0.2 \mathrm{mmol}$ ) was heated at reflux for $6 \mathrm{~h}$ under $\mathrm{N}_{2}$ atmosphere in $30 \mathrm{~mL}$ of $9: 1$ glycol and water mixture. The reaction mixture was diluted with $80 \mathrm{~mL}$ of water after the solution was cooled to room temperature. Then, the mixture was filtered, and excess sodium perchlorate was added to obtain an orange solid. The crude products were filtered and washed with cooled water and ether, and purified by flash silica gel 
column chromatography to afford a red powder. The reaction yield was 67\%. ESI-MS (in $\mathrm{CH}_{3} \mathrm{CN}, \mathrm{m} / \mathrm{z}$ ): $843.1\left[{\mathrm{M}-\mathrm{ClO}_{4}}^{-}\right]^{+}$and $372.5\left[\mathrm{M}-2 \mathrm{ClO}_{4}{ }^{-}\right]^{2+}$ (Fig. S1A $\dagger$ ). ${ }^{1} \mathrm{H}$ NMR (500 MHz, DMSO- $d^{6}$ ) $\delta 9.61(\mathrm{~d}, J=1.2 \mathrm{~Hz}, 1 \mathrm{H}), 9.59-9.59(\mathrm{~m}, 1 \mathrm{H}), 8.81(\mathrm{~d}, J=1.2 \mathrm{~Hz}$, $1 \mathrm{H}), 8.80(\mathrm{t}, J=1.3 \mathrm{~Hz}, 2 \mathrm{H}), 8.78(\mathrm{~d}, J=1.3 \mathrm{~Hz}, 1 \mathrm{H}), 8.52(\mathrm{dt}, J=$ $6.4,3.2 \mathrm{~Hz}, 2 \mathrm{H}), 8.41$ (s, $4 \mathrm{H}), 8.28$ (dt, $J=4.5,2.3 \mathrm{~Hz}, 2 \mathrm{H}), 8.21-$ $8.18(\mathrm{~m}, 4 \mathrm{H}), 8.07(\mathrm{dd}, J=5.2,1.2 \mathrm{~Hz}, 2 \mathrm{H}), 7.90(\mathrm{dd}, J=6.8$, $4.0 \mathrm{~Hz}, 2 \mathrm{H}), 7.82(\mathrm{dd}, J=8.3,5.3 \mathrm{~Hz}, 2 \mathrm{H}), 7.78(\mathrm{dd}, J=8.3$, $5.3 \mathrm{~Hz}, 2 \mathrm{H}$ ) (Fig. S2A $\dagger) .{ }^{13} \mathrm{C}$ NMR (126 MHz, DMSO- $d^{6}$ ) $\delta 153.96$ (s), 153.31 (s), 152.69 (s), 150.76 (s), 147.15 (s), 141.93 (s), 140.21 (s), 136.97 (s), 133.21 (s), 132.60 (s), 130.49 (d, $J=2.8 \mathrm{~Hz}), 130.10$ (s), 129.45 (s), 128.09 (s), 127.55 (s), 126.32 (d, $J=13.0 \mathrm{~Hz}$ ) (Fig. S3A $\dagger$ ).

Synthesis of $\left[\mathrm{Ru}(\text { phen })_{2}(\mathrm{Br}-\mathrm{dppz})\right]\left(\mathrm{ClO}_{4}\right)_{2}$ (2). 2 was prepared in a similar method but with $\left[\mathrm{Ru}(\text { phen })_{2} \mathrm{Cl}_{2}\right] \cdot 2 \mathrm{H}_{2} \mathrm{O}(103.9 \mathrm{mg}$, $0.2 \mathrm{mmol}$ ), Br-dppz (72 mg, $0.2 \mathrm{mmol}$ ). Yield: 61\%. ESI-MS (in $\left.\mathrm{CH}_{3} \mathrm{CN}, \quad m / z\right): \quad 922.9\left[{\mathrm{M}-\mathrm{ClO}_{4}}^{-}\right]^{+}$and $412.3\left[\mathrm{M}-2 \mathrm{ClO}_{4}{ }^{-}\right]^{2+}$ (Fig. S1B $\dagger$ ). ${ }^{1} \mathrm{H}$ NMR (500 MHz, DMSO- $\left.d^{6}\right) \delta 9.52(\mathrm{~d}, J=1.2 \mathrm{~Hz}$, $1 \mathrm{H}), 9.50$ (dd, $J=2.4,1.3 \mathrm{~Hz}, 1 \mathrm{H}), 9.48$ (d, $J=1.3 \mathrm{~Hz}, 1 \mathrm{H}), 8.83-$ $8.80(\mathrm{~m}, 2 \mathrm{H}), 8.80(\mathrm{~d}, J=1.0 \mathrm{~Hz}, 1 \mathrm{H}), 8.78(\mathrm{~s}, 1 \mathrm{H}), 8.63(\mathrm{~d}, J=$ $2.2 \mathrm{~Hz}, 1 \mathrm{H}), 8.41(\mathrm{~d}, J=1.2 \mathrm{~Hz}, 3 \mathrm{H}), 8.32(\mathrm{dt}, J=5.4,2.7 \mathrm{~Hz}, 1 \mathrm{H})$, $8.28(\mathrm{dd}, J=5.3,1.2 \mathrm{~Hz}, 1 \mathrm{H}), 8.25(\mathrm{t}, J=3.0 \mathrm{~Hz}, 1 \mathrm{H}), 8.23(\mathrm{dd}, J=$ $5.4,1.7 \mathrm{~Hz}, 1 \mathrm{H}), 8.21$ (dd, $J=4.5,2.5 \mathrm{~Hz}, 1 \mathrm{H}), 8.20$ (d, $J=1.3 \mathrm{~Hz}$, $1 \mathrm{H}), 8.08$ (ddd, $J=5.2,2.5,1.2 \mathrm{~Hz}, 2 \mathrm{H}), 7.92-7.87$ (m, 2H), 7.83 (td, $J=8.1,5.3 \mathrm{~Hz}, 2 \mathrm{H}), 7.78(\mathrm{dd}, J=8.3,5.3 \mathrm{~Hz}, 2 \mathrm{H})$ (Fig. S2B $\dagger$ ). ${ }^{13} \mathrm{C}$ NMR (126 MHz, DMSO- $d^{6}$ ): $\delta 154.24(\mathrm{~d}, J=19.1 \mathrm{~Hz}), 153.33$ (s), 152.70-152.54 (m), 150.79 (s), 147.13 (s), 142.22 (s), 140.75 (d, $J=20.3 \mathrm{~Hz}$ ), 140.46 (s), 137.01 (s), 135.60 (s), 133.24 (s), 131.21 (s), 130.52 (s), 129.82 (d, J=11.2 Hz), 128.09 (s), 127.65 (s), 126.33 (d, $J=14.4 \mathrm{~Hz}$ ), 125.92 (s) (Fig. S3B†).

\section{Preparation of the nanosized polymers}

$\mathrm{Ru}(\mathrm{II})$ complexes were dissolved by dimethyl sulfoxide and then diluted to $100 \mu \mathrm{M}$ solution by Tris- $\mathrm{HCl} \mathrm{KCl}$ or NaCl buffer ( $\mathrm{pH}$ $=7.2)([\mathrm{KCl}]=0.1 \mathrm{M},[\mathrm{NaCl}]=0.1 \mathrm{M})$. The oligonucleotides or CT-DNA were dissolved and diluted to $100 \mu \mathrm{M}$ solution by Tris$\mathrm{HCl} \mathrm{KCl}$ or NaCl buffer $(\mathrm{pH}=7.2)([\mathrm{KCl}]=0.1 \mathrm{M},[\mathrm{NaCl}]=0.1$ $\mathrm{M})$. The oligonucleotides or CT-DNA solution $(100 \mu \mathrm{M})$ and were well mixed with the same volume of $\mathrm{Ru}(\mathrm{II})$ complexes $(100 \mu \mathrm{M})$ in an Eppendorf tube at room temperature for $72 \mathrm{~h}$.

\section{AFM observation}

A $100 \mu \mathrm{L}$ mixed solution was added to a copper wire mesh and naturally volatilized for $2 \mathrm{~h}$. The mixture of oligonucleotide solution $(100 \mu \mathrm{M})$ or CT-DNA solution $(100 \mu \mathrm{M})$ was incubated with $\mathrm{Ru}(\mathrm{II})$ complexes $(100 \mu \mathrm{M})$ for 3 days. Next, a $10 \mu \mathrm{L}$ mixed solution was removed to a mica plate and naturally volatilized for $2 \mathrm{~h}$. An image of the sample was captured by AFM (Bruker, Dimension FastScanTM).

\section{Viscosity measurements}

The viscosity measurement is an effective method to judge the interaction mode of $\mathrm{Ru}$ (II) complexes with DNA. Fixed solutions of complexes and DNA in different concentrations were prepared in Tris-HCl buffer media, with $[\mathrm{Ru}] /[\mathrm{DNA}]=0,0.02$, $0.04,0.06,0.08,0.1$. Before testing, the solutions were stored in a thermostatic water bath at $\left(30 \pm 0.1{ }^{\circ} \mathrm{C}\right) 1 \mathrm{~h}$. The formula calculated viscosity is: $\eta=\left(t-t_{0}\right) / t_{0}$. Viscosity curves were obtained using $\left(\eta / \eta_{0}\right)^{1 / 3}$ as the $Y$-axis and with $r(r=[\mathrm{Ru}] /[\mathrm{DNA}])$ as the $X$-axis.

\section{Transmission electron microscope (TEM) observation}

The mixture of oligonucleotide solution $(100 \mu \mathrm{M})$ or CT-DNA solution $(100 \mu \mathrm{M})$ was incubated with $\mathrm{Ru}(\mathrm{II})$ complexes (100 $\mu \mathrm{M})$ for $24 \mathrm{~h}$. A $20 \mu \mathrm{L}$ mixed solution was added to a copper wire mesh and naturally volatilized for three times. The images of the samples were obtained on TEM (Hitachi Ltd, Tokyo, Japan).

\section{Particle size observation}

The mixture of oligonucleotide solution $(10 \mu \mathrm{M})$ or CT-DNA solution $(10 \mu \mathrm{M})$ was incubated with $\mathrm{Ru}(\mathrm{II})$ complexes $(10 \mu \mathrm{M})$. The particle size change of the samples varied with time, were obtained on Zetasizer Nano ZS (Malvern, Britain).

\section{Fluorescence emission titrations}

Fluorescence spectroscopy was performed on a RF-5301 fluorescence spectrophotometer using a $1 \mathrm{~cm}$ path length quartz cell. Luminescence titrations of Ru(II) complexes were measured by using a fixed $\mathrm{Ru}(\mathrm{II})$ concentration $(100 \mu \mathrm{M})$ with increasing CT-DNA or oligonucleotides. The first spectrum was obtained after $5 \mathrm{~min}$ to allow the sample $(3000 \mu \mathrm{L})$ to equilibrate. Then, 2 $\mu \mathrm{L}$ of the $100 \mu \mathrm{M}$ DNA solution was added to the sample cell with thorough mixing. The titration processes were repeated until no apparent change occurred in the spectra for at least three titrations, which indicated that binding saturation was achieved. ${ }^{54}$

\section{Electronic absorption spectra}

The electronic absorption spectra were obtained on a Shimadzu UV-2550 spectrophotometer using $1 \mathrm{~cm}$ path length quartz cuvettes $(3 \mathrm{~mL})$. The absorption titration of the $\mathrm{Ru}(\mathrm{II})$ complex in Tris-HCl buffer was performed by using a fixed complex concentration, to which increments of the DNA stock solution were added. The concentration of the complex solution was 20 $\mu \mathrm{M}$, and CT-DNA or oligonucleotides were added by degrees. Complex-DNA solutions were incubated for $3 \mathrm{~min}$ before the absorption spectra were recorded. ${ }^{51}$

\section{CD spectroscopy}

The CD spectra were obtained on a Jasco J810 circular dichroism (CD) spectrophotometer with a thermoelectrically controlled cell holder. The cell path length was $1 \mathrm{~cm}$. The CD spectra were obtained in the range of $230-600 \mathrm{~nm}$ at $0.5 \mathrm{~nm}$ increments with an averaging time of $0.5 \mathrm{~s}^{55}$

\section{Cellular imaging}

MDA-MB-231 cells were purchased from American Type Culture Collection (ATCC, Manassas, VA, USA). The cell lines of MDAMB-231 were maintained in DMEM with fetal bovine serum (10\%), penicillin (100 units per $\mathrm{mL}$ ), and streptomycin (50 units per $\mathrm{mL}$ ) at $37^{\circ} \mathrm{C}$ in a $\mathrm{CO}_{2}$ incubator (95\% relative humidity, $5 \%$ 
$\mathrm{CO}_{2}$ ). MDA-MB-231 cells were resuspended in 10\% FBS DMEM at a density of $2.5 \times 10^{4}$ cells per $\mathrm{mL}$, which were then treated with drugs and incubated for $24 \mathrm{~h}$ at $37^{\circ} \mathrm{C}$, unless otherwise stated. Cells were washed thrice in PBS. Cell morphology was observed by laser confocal microscope.

\section{Selectively imaging tumor cells by Ru(II)@oligonucleotide in zebra fish xenografts model}

The establishment of zebrafish embryo breast cancer model was performed by the description of the related literature. ${ }^{50}$ Juvenile zebrafish of breast cancer model ( $72 \mathrm{~h}$ old) were incubated in 24-well plates (10 fishes in every well) with $1 \mathrm{~mL}$ solutions with 1@oligonucleotides and 2@oligonucleotides $(2.5 \mu \mathrm{M})$ in aquaculture water. The localization of 1@oligonucleotides and 2@oligonucleotides in breast cancer zebrafish were observed every $24 \mathrm{~h}$ with a fluorescence microscopy. The relevant ethical protocols used for the in vivo study for zebrafish were performed in compliance with relevant laws or guidelines and were followed institutional guidelines. The animals were maintained in accordance with the Guide for the Care and Use of Laboratory Animals issued by the National Institutes of Health, and approved by the Laboratory Animal Ethics Committee of Guangdong Pharmaceutical University.

\section{Conflicts of interest}

There are no conflicts of interest to declare.

\section{Acknowledgements}

This work was supported by National Nature Science Foundation of China (81572926, 81703349), the Provincial Major Scientific Research Projects in Universities of Guangdong Province (2014KZDXM053), the Science and Technology Project of Guangdong Province (2014A020212312), the Innovation Projects in Universities of Guangdong Province (2015cxqx151), Tradition Chinese Medicine Bureau of Guangdong Province (20151265), the Innovation Team Projects in Universities of Guangdong Province (2016KCXTD018), Provincial College Students Innovation and Entrepreneurship Training Program of Guangdong Province (51307173), National College Students Innovation and Entrepreneurship Training Program (51307164).

\section{Notes and references}

1 T. Vo-Dinh, J. Wang, J. R. Lakowicz, P. T. Vernier, Y. Sun, Z. K. Gryczynski, M. A. Gundersen and L. Marcu, Proc. SPIE, 2005, 5703, 127.

2 R. J. Antcliff, M. R. Stanford, D. S. Chauhan, E. M. Graham, D. J. Spalton, J. S. Shilling, T. J. Ffytche and J. Marshall, Ophthalmology, 2000, 107, 593-599.

3 H. Kobayashi, M. Ogawa, R. Alford, P. L. Choyke and Y. Urano, Chem. Rev., 2010, 110, 2620-2640.

4 Q. R. Tummers, C. E. Hoogstins, K. N. Gaarenstroom, C. D. de Kroon, M. I. van Poelgeest, J. Vuyk, T. Bosse,
V. T. Smit, C. J. van de Velde, A. F. Cohen, P. S. Low, J. Burggraaf and A. L. Vahrmeijer, Oncotarget, 2016, 7, 32144-32155.

5 J. Zhang, R. E. Campbell, A. Y. Ting and R. Y. Tsien, Nat. Rev. Mol. Cell Biol., 2002, 3, 906-918.

6 W. R. Freeman, D. U. Bartsch, A. J. Mueller, A. S. Banker and R. N. Weinreb, Clin. Sci., 1998, 116, 455-463.

7 V. Fernandez-Moreira, F. L. Thorp-Greenwood and M. P. Coogan, Chem. Commun., 2010, 46, 186-202.

8 M. R. Gill and J. A. Thomas, Chem. Soc. Rev., 2012, 41, 31793192.

9 K. E. Erkkila, D. T. Odom and J. K. Barton, Chem. Rev., 1999, 99, 2777-2795.

10 M. R. Gill, H. Derrat, C. G. Smythe, G. Battaglia and J. A. Thomas, ChemBioChem, 2011, 12, 877-880.

11 A. E. Friedman, J.-C. Chambron, J.-P. Sauvage, N. J. Turro and J. K. Barton, J. Am. Chem. Soc., 1990, 112, 4960-4962.

12 X. Q. Guo, F. N. Castellano, L. Li and J. R. Lakowicz, Biophys. Chem., 1998, 71, 51-62.

13 M. R. Gill, D. Cecchin, M. G. Walker, R. S. Mulla, G. Battaglia, C. Smythe and J. A. Thomas, Chem. Sci., 2013, 4, 4512-4519.

14 H. Huang, B. Yu, P. Zhang, J. Huang, Y. Chen, G. Gasser, L. Ji and H. Chao, Angew. Chem., Int. Ed., 2015, 54, 14049-14052.

15 C. Qian, J. Q. Wang, C. L. Song, L. L. Wang, L. N. Ji and H. Chao, Metallomics, 2013, 5, 844-854.

16 Z. P. Zeng, Q. Wu, F. Y. Sun, K. D. Zheng and W. J. Mei, Inorg. Chem., 2016, 55, 5710-5718.

17 U. Neugebauer, Y. Pellegrin, M. Devocelle, R. J. Forster, W. Signac, N. Moran and T. E. Keyes, Chem. Commun., 2008, 42, 5307-5309.

18 C. A. Puckett and J. K. Barton, J. Am. Chem. Soc., 2009, 131, 8738-8739.

19 K. Kam-Wing Lo, T. K.-M. Lee, J. S.-Y. Lau, W.-L. Poon and S.-H. Cheng, Inorg. Chem., 2008, 47, 200-208.

20 L. Blackmore, R. Moriarty, C. Dolan, K. Adamson, R. J. Forster, M. Devocelle and T. E. Keyes, Chem. Commun., 2013, 49, 2658-2660.

21 R. Langer, Nature, 1998, 392, 5-10.

22 D. Schrama, R. A. Reisfeld and J. C. Becker, Nat. Rev. Drug Discovery, 2006, 5, 147-159.

23 S. M. Nimjee, C. P. Rusconi and B. A. Sullenger, Annu. Rev. Med., 2005, 56, 555-583.

24 A. Corti and M. Ponzoni, Ann. N. Y. Acad. Sci., 2004, 1028, 104-112.

25 M. Goldberg, R. Langer and X. Jia, J. Biomater. Sci., Polym. Ed., 2007, 18, 241-268.

26 E. Ruoslahti, S. N. Bhatia and M. J. Sailor, J. Cell Biol., 2010, 188, 759-768.

27 C. D. Irene Brigger and P. Couvreur, Adv. Drug Delivery Rev., 2002, 54, 631-651.

28 J. C. E. A. Sykes, G. Zheng and W. C. W. Chan, ACS Nano, 2014, 8, 5696-5706.

29 S. D. Perrault, C. Walkey, T. Jennings, H. C. Fischer and W. C. W. Chan, Nano Lett., 2009, 9, 1909-1915.

30 B. Subia and S. C. Kundu, Nanotechnology, 2013, 24, 035103. 31 L. Wu, L. Zhang, G. Shi and C. Ni, Mater. Sci. Eng., C, 2016, 61, 278-285. 
32 Q. Wu, W. Mei, K. Zheng and Y. Ding, Sci. Rep., 2016, 6, 28582.

33 K. Qiu, B. Yu, H. Huang, P. Zhang, J. Huang, S. Zou, Y. Chen, L. Ji and H. Chao, Sci. Rep., 2015, 5, 10707.

34 B. Yu, C. Ouyang, K. Qiu, J. Zhao, L. Ji and H. Chao, Chem.Eur. J., 2015, 21, 3691-3700.

35 B. Yu, Y. Chen, C. Ouyang, H. Huang, L. Ji and H. Chao, Chem. Commun., 2013, 49, 810-812.

36 L. Liu, H. Zhang, X. Meng, J. Yin, D. Li and C. Liu, Biomaterials, 2010, 31, 1380-1391.

37 G. L. Liao, X. Chen, L. N. Ji and H. Chao, Chem. Commun., 2012, 48, 10781-10783.

38 Y. Jenkins, A. E. Friedman, N. J. Turro and J. K. Barton, Biochemistry, 1992, 31, 10809-10816.

39 S. A. Poteet, M. B. Majewski, Z. S. Breitbach, C. A. Griffith, S. Singh, D. W. Armstrong, M. O. Wolf and F. M. MacDonnell, J. Am. Chem. Soc., 2013, 135, 2419-2422.

40 H. J. Yu, L. Yu, Z. F. Hao and Y. Zhao, Spectrochim. Acta, Part A, 2014, 124, 187-193.

41 M. Balaz, B. C. Li, J. D. Steinkruger, G. A. Ellestad, K. Nakanishi and N. Berova, Org. Biomol. Chem., 2006, 4, 1865-1867.

42 S. Mahadevan and M. Palaniandavar, Inorg. Chem., 1998, 37, 3927-3934.

43 X. Qu, J. O. Trent, I. Fokt, W. Priebe and J. B. Chaires, Proc. Natl. Acad. Sci. U. S. A., 2000, 97, 12032-12037.

44 D. Mazumdar, N. Nagraj, H.-K. Kim, X. Meng, A. K. Brown, Q. Sun, W. Li and Y. Lu, J. Am. Chem. Soc., 2009, 131, 5506-5515.
45 N. Shimada, A. Kano and A. Maruyama, Adv. Funct. Mater., 2009, 19, 3590-3595.

46 M. Balaz, A. E. Holmes, M. Benedetti, G. Proni and N. Berova, Bioorg. Med. Chem., 2005, 13, 2413-2421.

47 M. Balaz, A. E. Holmes, M. Benedetti, P. C. Rodriguez, N. Berova, K. Nakanishi and G. Proni, J. Am. Chem. Soc., 2005, 127, 4172-4173.

48 A. H.-J. Wang, G. J. Quigley, F. J. Kolpak, J. L. Crawford, J. H. V. Boom, G. van der Marel and A. Rich, Nature, 1980, 282, 680-686.

49 S. S. Bhat, A. S. Kumbhar, A. A. Kumbhar, A. Khan, P. Lonnecke and E. Hey-Hawkins, Chem. Commun., 2011, 47, 11068-11070.

50 J. Wang, Z. Cao, X. M. Zhang, M. Nakamura, M. Sun, J. Hartman, R. A. Harris, Y. Sun and Y. Cao, Cancer Res., 2015, 75, 306-315.

51 V. G. Vaidyanathan and B. U. Nair, J. Inorg. Biochem., 2002, 91, 405-412.

52 C. Hiort, P. Lincoln and B. Norden, J. Am. Chem. Soc., 1993, 115, 3448-3454.

53 E. Amouyal, A. Homsi, J.-C. Chambron and J.-P. Sauvage, J. Chem. Soc., Dalton Trans., 1990, 6, 1841-1845.

54 X. H. Lu, S. Shi, J. L. Yao, X. Gao, H. L. Huang and T. M. Yao, J. Inorg. Biochem., 2014, 140, 64-71.

55 P. U. Maheswari, V. Rajendiran, M. Palaniandavar, R. Parthasarathi and V. Subramanian, J. Inorg. Biochem., 2006, 100, 3-17. 